\title{
Is Decentralisation in Ghana pro-poor?
}

Commonwealth Journal of Local Governance

Issue 6: July 2010

http:/lepress.lib.uts.edu.au/ojs/index.php/cjlg

\section{Franklin Obeng-Odoom}

Department of Political Economy

The University of Sydney ${ }^{1}$

\section{Introduction}

There is a popular belief among decentralists that if local governments have the power to generate and spend revenue, without relying on central government funding, their expenditure will be pro-poor and will improve the lives of local people. Such views have influenced recent calls for greater decentralisation in developing countries in general and Africa in particular. However, evidence from Ghana casts some doubts on this view. A brief comparison of the expenditure and revenue patterns of the poorest and richest local governments there suggests that local governments are not inherently pro-poor and that locally generated funds might be used in ways that do not reflect the needs of the locality as a whole. Thus the fiscal devolution view of decentralisation appears to be out of kilter with reality. To discuss this issue, the three sections in this paper summarise the assumptions and perceived benefits of decentralisation, describe decentralisation in Ghana, and analyse the revenue and expenditure patterns of the Kumasi Metropolitan Authority and the Kasena Nankana District Assembly.

\section{Decentralisation and local governance}

Decentralisation involves the transfer of power, whether political, administrative or fiscal in one of four forms: Deconcentration (the handing over of administrative or managerial responsibility to sub-national governments); Delegation (establishing public enterprises and other semi-autonomous bodies to manage sectors like utilities); Devolution (the transfer of decision-making authority); and Privatisation (the transfer of

\footnotetext{
${ }^{1} \mathrm{PhD}$ candidate. The author is grateful to Kenneth Wemochiga and Owusu Mensah for assisting in assembling the data used in this essay. They are not responsible for the interpretation of the data.
} 
hitherto state-managed corporations to the private sector) (Martinussen 1997:210-211). The underlying assumptions of decentralisation are:

- Sub-national governments are closer to the people;

- Sub-national governments know what their people want;

- Sub-national governments have local information about resources, the incomes of their citizens, and local business conditions in their areas of jurisdiction;

- Sub-national governments can be influenced in their decisions/actions by local stakeholders; and

- Sub-national governments are accountable to their communities.

Based on these assumptions, proponents believe that decentralisation leads to the following beneficial outcomes (See Smoke 2003; World Bank 2003 for detailed discussion):

- Improved 'allocative efficiency' - what will best suit local people at least cost;

- Improved service monitoring by both sub-national governments and local people;

- Improved participatory governance;

- Improved redistribution of income ;

- Improved resource mobilisation;

- Improved service provision and infrastructure; and

- Improved local economic development and poverty reduction.

Given the enormous support decentralisation and local governance enjoys among development planners, there is the need to periodically evaluate its impacts. One of the key propositions for decentralization (and recurrent desire among development planners) is its claimed ability to enhance revenue generation at the local level and, thus, to ensure that local governments are adequately resourced. With enough resources, decentralists believe, local governments can provide the necessary infrastructure and services to ensure rapid poverty reduction (see, for example, UN-Habitat 2001; Bird 1995). However, several evaluations have concluded that in the Third World, especially in Africa, little revenue is generated at the local level. Annually, sub-Saharan African cities generate only US\$14 per capita compared to US\$2,906 in the highly industrialised countries and US\$153 in Asia (UN-Habitat 2001). As such, there is a current flurry of interest in how to increase local revenue mobilisation in Africa. What is often taken for 
granted is how existing revenue is used and whether the expenditure and revenue patterns of local governments are pro-poor. The prevailing assumption is that local revenue is used in ways that lead to the reduction of poverty levels. Efficiency requires that the validity of this assumption be ascertained before rushing to generate more revenue. Ghana provides a good 'laboratory' to conduct this 'experiment' because it has a long history of decentralisation.

\section{Decentralisation in Ghana}

As part of the economic reforms that were implemented in Ghana in the 1980s, a new system of local governance was adopted. There are currently 170 local governments charged with the responsibility of promoting local economic development. Based on population size, these local governments may be regarded as metropolitan (settlements of over 250,000 people), municipal (settlements of over 95,000 people), or district assemblies (settlements of over 75,000 people). There are 6 metropolitan authorities, 39 municipal authorities and 125 district assemblies (Obeng-Odoom 2009). These local governments face several problems, including the lack of requisite technocrats, especially planners; logistical constraints; and, the lack of autonomy from central government (Lentz, 2006; Mensah 2005). Of all these problems, revenue generation is the most challenging, prompting many decentralists and planners (e.g. Mensah, 2005) to suggest possible ways of attaining more revenues for the assemblies. But, again, how effectively the little revenue generated has been put to use remains an unanswered question.

\section{Financial trends: Two local governments compared}

The revenue and expenditure patterns of one of the richest local governments in Ghana the Kumasi Metropolitan Authority - was analysed alongside one of the poorest, the Kasena Nankana District Assembly. In the Kasena Nankana District Assembly, capital expenditure has decreased over time, from $83 \%$ in 2003 to $12.5 \%$ in 2006, while recurrent expenditure (internal costs of running the council) has increased from $17 \%$ to over $87 \%$ over the same period, as shown in table 1 :

Table 1: Capital and Recurrent Expenditure in Kasena Nankana District Assembly

\begin{tabular}{c|c|c}
\hline Year & $\begin{array}{c}\text { Capital expenditure as a share } \\
\text { of Internally Generated Funds } \\
\text { (IGF) }\end{array}$ & $\begin{array}{c}\text { Recurrent expenditure as a } \\
\text { share of IGF }\end{array}$ \\
\hline 2003 & $83.0 \%$ & $17.0 \%$ \\
\hline 2004 & $94.7 \%$ & $5.3 \%$ \\
\hline
\end{tabular}




\begin{tabular}{c|c|c}
\hline 2005 & $90.0 \%$ & $10.0 \%$ \\
\hline 2006 & $12.5 \%$ & $87.5 \%$ \\
\hline
\end{tabular}

Source: Kasena Nankana District Assembly, 2007

A similar trend can be observed in the revenue and expenditure patterns of the relatively rich local governments in Ghana. These trends are the same in the richest local government too. At the Kumasi Metropolitan Authority, there is insufficient effort to spend municipal funds in a way to ensure that the poor might benefit. The revenue and expenditure statement for the year 2008 shows that total recurrent expenditure (49.4\%) was almost the same as total capital expenditure (50.6\%). Such expenditure patterns evidently suggest that local governments are paying more attention to administrative issues like printing, photocopying and furnishing local government offices than direct capital investment in development projects that would ensure improving the living conditions of local people.

Central government grants to local governments are also far from being spent in a propoor manner. Table 2 shows that until 2006, the Kasena Nankana District Assembly spent the bulk of its revenue on 'good governance', which, from the reports of the assembly, seems to be defined as the administration of local government offices.

Table 2: Distribution of expenditure from government grant in Kasena Nankana

\begin{tabular}{c|c|c|c}
\hline Year & Education & Health & Good Governance \\
\hline 2003 & $15.8 \%$ & $2.7 \%$ & $81.5 \%$ \\
\hline 2004 & $10.4 \%$ & $24.0 \%$ & $65.6 \%$ \\
\hline 2005 & $22.3 \%$ & $11.5 \%$ & $66.2 \%$ \\
\hline 2006 & $17.1 \%$ & $64.3 \%$ & $18.6 \%$ \\
\hline
\end{tabular}

Source: Kasena Nankana District Assembly, 2007

Interestingly, there was a significant decline in the share of central government grant that is used for 'good governance' in 2006. It is not immediately clear what might have caused this decline. A possible explanation is that some items of expenditure had been incorrectly classified prior to 2006 and this error was corrected in 2006. It may be asked whether that explanation represents the end of the evidence about the lack of pro-poor local governance? 
Related concerns exist. One other aspect of the nexus between local finance and poverty reduction that gives cause for concern is the nature of revenue collection. One key area where government can influence the distribution of income in the local economy is through taxation. Land taxation, for example, can serve as a vehicle for the redistribution of wealth because it falls on assets that are (disproportionately) owned by more wealthy citizens. Revenue from land taxes could be invested in the provision of healthcare, agriculture and education to drive the local economy in ways in which the poor can benefit. However, though local governments in Ghana have the power to levy property rates, little is actually collected.

Tables 3 and 4 show the sources of funds to the Kasena Nankana District Assembly and the Kumasi Metropolitan Authority respectively. In both cases, a government grant is the biggest source of revenue, accounting for an average of over $90 \%$ of revenue in Kasena and over 65\% in Kumasi. Other important sources of funds are fees from sources like lorry parks and street parking, and fines imposed by the law courts. Licenses extended to people, such as those who hawk their wares or display them in kiosks, also bring some income to the local governments. Rates are very low in Kasena, accounting for less than 1\% of revenue from 2003 to 2006.

Table 3: Sources of Funds to the Kasena Nankana District Assembly

\begin{tabular}{c|c|c|c|c}
\hline Source & $\mathbf{2 0 0 3}$ & $\mathbf{2 0 0 4}$ & $\mathbf{2 0 0 5}$ & $\mathbf{2 0 0 6}$ \\
\hline Grant & $89.7 \%$ & $95.3 \%$ & $95.4 \%$ & $94.4 \%$ \\
\hline Fees and Fines & $8.1 \%$ & $3.8 \%$ & $3.3 \%$ & $0.3 \%$ \\
\hline Miscellaneous & $0.5 \%$ & $0.0 \%$ & $0.2 \%$ & $0.6 \%$ \\
\hline Licenses & $0.9 \%$ & $0.3 \%$ & $0.6 \%$ & $0.8 \%$ \\
\hline Rent & $0.5 \%$ & $0.2 \%$ & $0.3 \%$ & $0.5 \%$ \\
\hline $\begin{array}{c}\text { Investment } \\
\text { Income }\end{array}$ & $0.3 \%$ & $0.3 \%$ & $0.2 \%$ & $3.0 \%$ \\
\hline Lands & $0.0 \%$ & $0.0 \%$ & $0.0 \%$ & $0.1 \%$ \\
\hline Rate & $0.0 \%$ & $0.0 \%$ & $0.0 \%$ & $0.3 \%$ \\
\hline
\end{tabular}

Table 4: Sources of Funds to the Kumasi Metropolitan Authority

\begin{tabular}{c|c|c|c}
\hline Source & $\mathbf{2 0 0 6}$ & $\mathbf{2 0 0 7}$ & $\mathbf{2 0 0 8}^{\mathbf{2}}$ \\
\hline Grants & $75.9 \%$ & $75.9 \%$ & $44.6 \%$ \\
\hline Fees/Fines & $9.3 \%$ & $9.3 \%$ & $17.5 \%$ \\
\hline Licenses & $5.8 \%$ & $5.8 \%$ & $15.4 \%$ \\
\hline Rates & $5.6 \%$ & $5.6 \%$ & $16.7 \%$ \\
\hline Rent & $1.7 \%$ & $1.7 \%$ & $2.4 \%$ \\
\hline Lands & $1.1 \%$ & $1.1 \%$ & $2.9 \%$ \\
\hline Miscellaneous & $0.4 \%$ & $0.4 \%$ & $0.4 \%$ \\
\hline Investment & $0.2 \%$ & $0.2 \%$ & $0.1 \%$ \\
\hline
\end{tabular}

\footnotetext{
2 These are projections.
} 
The implication is that the gap between rich and poor may be widening because the rich and owners of property are not paying as much in taxes as by law they should. This situation has negative implications for the distribution of income in the country as a whole. Some recent surveys, conducted in 1998, 1999 and 2009, show that the income of the poorest $10 \%$ of the people in Ghana has reduced from $2.4 \%$ to $2.0 \%$ (UNDP 2009:197; UNDP 2001:184). Simultaneously, the share of the income of the richest $10 \%$ of the population has increased from 29.5\% in 1998 to 30.1\% in 1999 and 32.8\% in 2009 (UNDP 2001; 2002; 2009). International evidence shows that such inequality has adverse effects for economic growth, happiness and poverty reduction (Fosu 2008; Birdsall et al. 1994; Stilwell and Jordan 2007).

\section{Conclusion}

So is decentralisation in Ghana pro-poor? The evidence considered thus far cannot be said to be conclusive. Nevertheless, it suggests that there are not sufficient compelling reasons to believe that the practice of decentralisation is propitious as far as equity and local economic development are concerned. Clearly, the problem with local government finance in Ghana is not only increasing the amount of locally generated revenue but also ensuring that the existing 'stock' of local revenue is expended in ways to ensure a reduction in income inequality and poverty levels at the local level.

To meet this aspiration, some lessons can be learnt from the participatory budgeting process in Porto Alegre, Brazil. There, ordinary citizens lead the process of determining their local needs. This system, according to informed observers (e.g. Social Development Family 2003), has radically changed a techno-bureaucratic budgeting procedure to a 'techno-democratic' process in which common people play a significant role in determining ways of generating resources and how resources already generated should be utilized to shape their future.

\section{References:}

Bird R. 1995. 'Financing Local Services: Patterns, Problems and Possibilities', Major Report 31, University of Toronto, Centre for Community and Urban Services.

Fosu A. 2008. 'Inequality and the impact of growth on poverty: comparative evidence for subSaharan Africa', Journal of Development Studies, vol. 45, no.5, pp. 726-745.

Kasena Nankana District Assembly, ‘District Profile-Kasena Nankana District', Kasena Nankana District Assembly, Ghana. 
Kumasi Metropolitan Authority, 2009. 'Revenue and expenditure estimates for 2008', Kumasi Metropolitan Authority, Kumasi.

Lentz D, 2006. 'Decentralization, the State and Conflicts over Local Boundaries in Northern Ghana', Development and Change, vol. 37, no.4, pp.901-919.

Martinussen J., 1997. Society, State and Market, Zed Books.

Mensah J, 2005. 'Problems of District Medium-Term Development Plan implementation in Ghana, The way forward', International Development Planning Journal, 27(2), pp. 245270.

Obeng-Odoom F. 2009. 'Transforming Third World cities through good urban governance: Fresh evidence', Theoretical and Empirical Researches in Urban Management vol. 10, no. 1, pp.46-62.

Smoke P. 2003. 'Decentralisation in Africa: Goals, Dimensions, Myths and Challenges', public administration and development, vol. 23, pp.7-16.

Social Development Family, 2003.'Case study 2 - Porto Alegre, Brazil: Participatory Approaches in budgeting and public expenditure management', Social Development Notes, Note No. 71.

Stilwell F and Jordan K. 2007. Who gets what? Analysing economic inequality in Australia, Cambridge University Press, Melbourne.

UNDP, 2009. Human Development Report 2009, Palgrave Macmillan, New York.

UNDP, 2002. Human Development Report 2002, Oxford University Press, New York.

UNDP, 2001. Human Development Report 2001, Oxford University Press, New York.

UN-Habitat, 2001. State of the World's Cities, 2001, UN-Habitat.

World Bank, 2003. World Development Report 2004: Making Services Work for People, Oxford University Press, Oxford. 